https://jurnal.uns.ac.id/jdc

\title{
Pengembangan Kurikulum Pembelajaran di Masa Darurat
}

\author{
Ahmad Munajim ${ }^{1}$, Barnawi $^{2}$, Fikriyah $^{3}$ \\ 1,2,Institut Agama Islam Bunga Bangsa Cirebon, ${ }^{3}$ Universitas Muhammadiyah Cirebon \\ hajiahmadmunajim@gmail.com
}

\section{Sejarah Artikel}

diterima 28 Oktober 2020 disetujui 20 November 2020 diterbitkan 1 Desember 2020

\section{Abstract}

The impact of the Covid-19 pandemic on the education sector has resulted in a loss of generation. This article aims to describe the learning policy related to the impact of the Covid-19 pandemic. The method used in this article is the library research method with reference to emergency curriculum regulations. The results showed that the emergency program had great flexibility. The education unit has sufficient space to design curriculum structures, learning activities and learning materials, while remaining oriented towards knowledge development, character observation and improvement skills by deviating from health regulations and protocols.

Keywords: curriculum, covid - 19, learning emergency

Abstrak

Dampak pandemi covid-19 di bidang pendidikan mengarah ke lost generation. Artikel ini bertujuan mendeskripsikan kebijakan pembelajaran terkait dampak pandemi covid-19. Metode yang digunakan dalam artikel ini adalah metode penelitian pustaka dengan merujuk pada regulasi kurikulum darurat. Hasil penelitian menunjukkan bahwa bahwa kurikulum darurat memiliki fleksibilitas yang tinggi. Satuan pendidikan diberi ruang yang luas untuk mendesain struktur kurikulum, kegiatan pembelajaran, dan media pembelajaran dengan tetap berorientasi pada pengembangan pengetahuan, pengauatan karakter, dan peningkatan keterampilan dengan berangkat pada regulasi dan protokol kesehatan.
\end{abstract}

Kata Kunci: covid - 19, kurikulum, pembelajaran darurat 


\section{PENDAHULUAN}

Berdasarkan observasi npenulis pandemi covid-19 belum menunjukkan tanda-tanda akan segera berakhir. Hal ini berdampak pada semua bidang kehidupan manusia. Bidang ekonomi, sosial, budaya, seni, dan juga pendidikan merupakan bidang yang terdampak. $\mathrm{Di}$ bidang ekonomi terjadi perlambatan pertumbuhan ekonomi, pendapatan masyarakat sebagian besar mengalami penurunan yang drastis. Hal ini karena adanya kebijakan dan protokol kesehatan yang membuat ruang gerak produksi menyempit. Di bidang sosial terjadi pengurangan interaksi antarmanusia karena adanya physycal distancing. Di bidang budaya terjadi metamorfosa budaya yang dapat dicermati dari kebiasaan yang berubah. Di bidang seni, khususnya para seniman dan pekerja seni tidak ada lagi ruang aktualisasi secara fisik karena regulasi yang tidak memungkinkan terjadinya pertunjukkan dan pameran seni. Di bidang pendidikan, siswa tidak lagi dapat belajar langsung di kelas karena kepedulian kita terhadap keselamatan peserta didik. Akan tetapi mereduksi pembelajaran dalam rentang waktu yang panjang tidak saja mereduksi pengetahuan dan keterampilan peserta didik tetapi juga terhambatnya transfer of values sehingga secara nasional muncul ketakutan akan adanya lost generation.

Menurut Rizqon Halal Syah Aji (2020:396) ada dua dampak bagi keberlangsungan pendidikan yang disebabkan oleh pandemi Covid-19. Pertama adalah dampak jangka pendek, yang dirasakan oleh banyak keluarga di Indonesia baik di kota maupun di desa. $\mathrm{Di}$ Indonesia sebagian besar keluarga yang kurang familier melakukan sekolah di rumah semacam home schooling. Bersekolah di rumah bagi keluarga Indonesia adalah sebuah tradisi baru khususnya bagi produktivitas orang tua yang biasanya sibuk dengan pekerjaannya di luar rumah. Selain itu siswa mengalami problem psikologis karena terbiasa belajar bertatap muka langsung dengan guru-guru mereka. Seluruh elemen pendidikan secara kehidupan sosial "terpapar" sakit karena covid-19. Belum lagi persoalan infrastruktur pembelajaran yang tidak semua memiliki kapasitas melaksanakan pembelajaran online. Dampak yang kedua adalah dampak jangka panjang yakni aspek keadilan dan peningkatan ketidaksetaraan antar kelompok masyarakat dan antardaerah di Indonesia.

Atas dasar permasalahan di atas penulis memandang pentingnya membangun sistem pembelajaran di masa darurat. Dalam konteks pembelajaran darurat, pada tahun 2020 Kementerian Agama telah menyusun regulasi terkait kurikulum darurat. Kurikulum tersebut disusun dan dilampirkan dalam kurikulum tingkat satuan pendidikan dari level Madrasah Ibtidaiyah sampai dengan Madrasah Aliyah.

Undang-undang Nomor 20 tahun 2003 tentang Sistem Pendidikan Nasional, Pasal 36 mengamanatkan agar kurikulum pada semua jenjang dan jenis pendidikan disusun dan dikembangkan: (a) dengan prinsip diversifikasi sesuai dengan satuan pendidikan, potensi daerah, dan peserta didik, (b) sesuai dengan jenjang pendidikan dan (c) dalam rangka Negara Kesatuan Republik Indonesia. Berdasarkan 
Keputusan Direktur Jendral Pendidikan Islam Nomor 2781 Tahun 2020 tentang Panduan Kurikulum Darurat pada Madrasah dinyatakan bahwa Kurikulum Darurat adalah kurikulum tingkat satuan pendidikan yang disusun dan dilaksanakan oleh satuan pendidikan pada masa darurat. Masa darurat yang dimaksud bukan hanya pada masa darurat wabah Corona Virus Disease (Covid-19), tetapi berlaku pula pada masa darurat karena terjadi bencana alam, huruhara dan sebagainya.

Dalam Keputusan Direktur Jendral Pendidikan Islam Nomor 2781 Tahun 2020 tentang Panduan Kurikulum Darurat pada Madrasah tata kelola kurikulum menjadi lebih fleksibel. Sekolah tidak wajib menuntaskan kompetensi dasar sesuai regulasi yang berlaku (Permendikbud No 37 Tahun 2018 untuk materi umum dan KMA 183 tahun 2019 untuk rumpun agama).

Secara konseptual Kurikulum Darurat merupakan kurikulum yang disusun dan dilaksanakan oleh satuan pendidikan pada masa darurat. Oleh karena itu semua aspek yang berkenaan dengan perencanaan pembelajaran, kegiatan pembelajaran dan penilaian hasil belajar disesuaikan dengan kondisi darurat yang terdapat dan dirasakan oleh setiap satuan pendidikan madrasah. Mempertimbangkan kondisi darurat setiap daerah dan madrasah berbeda, maka implementasi kurikulum darurat setiap satuan pendidikan bisa berbeda-beda sesuai dengan kondisi dan kebutuhan masing-masing.

Regulasi yang dikeluarkan oleh Dirjen Pendis Kementerian Agama di atas memberi ruang yang luas bagi madrasah untuk mendesain kurikulum. Lembaga pendikan diberi kesempatan untuk menentukan struktur kurikulum yang esensial, menentukan pola pembelajaran, dan menentukan penilaian hasil belajar. Meskipun demikian madrasah harus tetap mengembangkan pembelajaran yang mengembangkan kompetensi siswa pada aspek sikap, aspek pengetahuan, aspek keterampilan.

Kegiatan pembelajaran harus menumbuhkembangkan kompetensi literasi bahasa, literasi matematik, literasi sains, literasi media, literasi teknologi dan literasi visual. Kegiatan pembelajaran juga harus dapat merangsang tumbuhnya 4C (Critical thinking, Collaborative, Creativity dan Communicative) pada diri siswa. Dan prasyarat wajibnya adalah kegiatan pembelajaran mempertimbangkan terjaganya kesehatan, keamanan,dan keselamatan civitas akademika baik pada aspek fisik maupun psikologi.

\section{METODE}

Metode yang digunakan dalam artikel ini adalah metode kualitatif. Ditinjau dari jenisnya artikel ini merupakan telaah pustaka. Penulis mencari dan menyusun dari berbagai referensi terkait dengan kurikulum darurat kemudian dianalisis secara deskriptif dalam sudut pandang pemikiran penulis dan regulasi terkait dengan kondisi daurat utamanya pandemi covid-19. Referensi utama sebagai bahan kajian adalah Keputusan Direktur Jendral Pendidikan Islam Nomor 2781 Tahun 2020 tentang Panduan Kurikulum Darurat pada Madrasah. 


\section{PEMBAHASAN}

Sesuai dengan tujuan penulisan artikel ini, aspek yang dikaji adalah kebijakan kurikulum di masa darurat khususnya pandemi covid-19.

1. Struktur Kurikulum di Masa Darurat Struktur kurikulum di masa darurat disusun dengan mereduksi struktur kurikulum pada masa normal menyangkut jumlah jam dan durasi atau waktu satu kali jam tatap muka. Sekolah/madrasah dapat memilih materi substansial, Sebagai contoh disajikan dalam tabel di bawah ini:

Tabel 1

Struktur Kurikulum Darurat Madrasah Ibtidaiyah

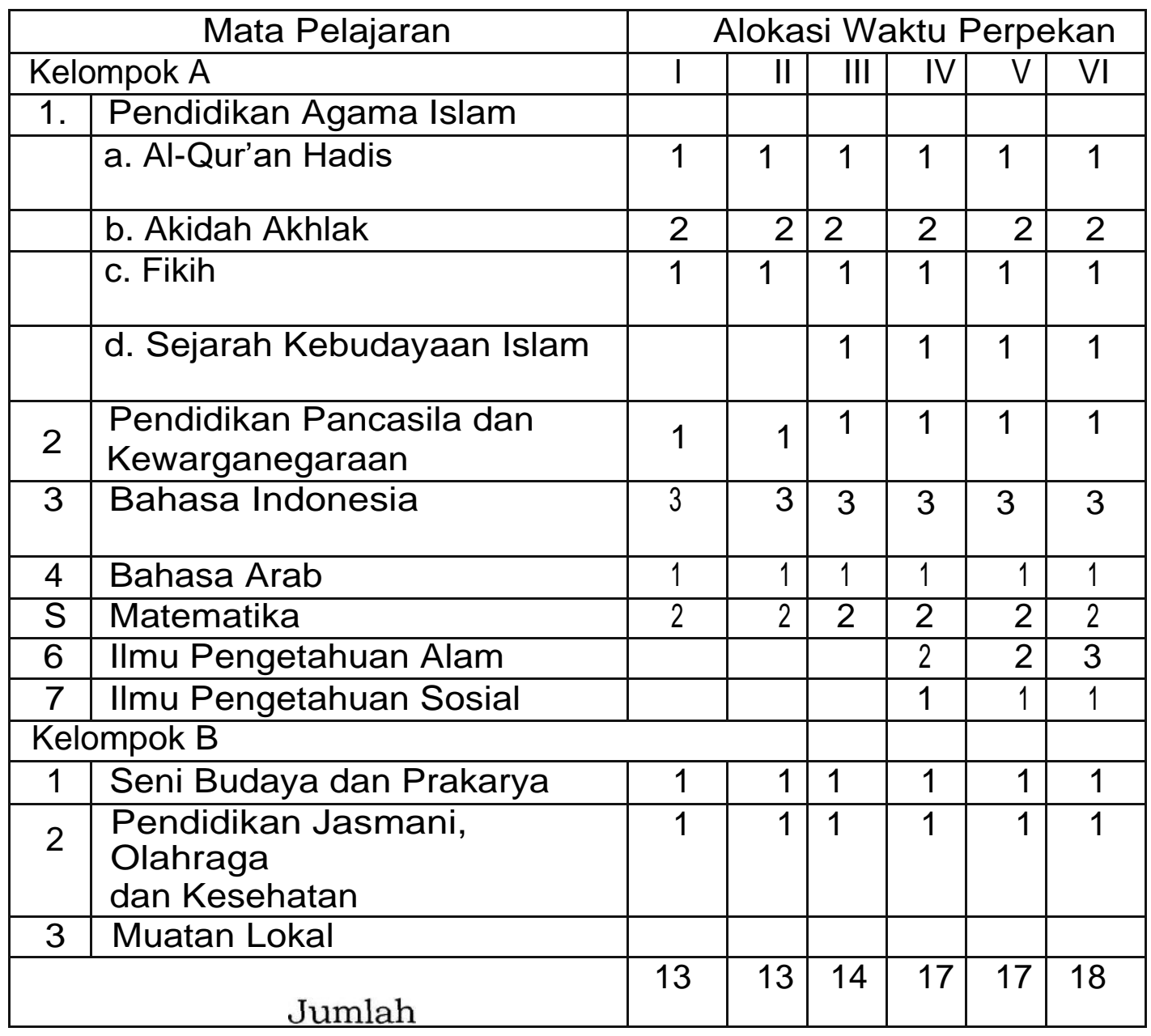

2. Pengembangan Materi Pembelajaran di Masa Darurat

Di masa darurat guru dapat memilih materi pelajaran esensi untuk menjadi prioritas dalam pembelajaran. Sedangkan materi lain dapat dipelajari siswa secara mandiri. Materi pembelajaran ditemukan dan dikumpulkan serta dikembangkan dari; buku-buku sumber seperti buku siswa, buku pedoman guru, maupun buku atau literatur lain yang berkaitan dengan ruang lingkup yang sesuai dan benar; hal-hal yang berkaitan dengan kehidupan dan/atau berkaitan dengan fenomena sosial yang bersifat kontekstual, misalnya berkaitan dengan pandemi Covid-19 atau hal 
lain yang sedang terjadi di sekitar siswa.

3. Model dan Metode Pembelajaran di Masa Darurat

Desain pembelajaran mengunakan pendekatan berbasis ilmiah/saintifik dapat berbentuk model-model pembelajaran, seperti model Pembelajaran Berbasis Penemuan (Discovery learning) model Pembelajaran Berbasis Penelitian (Inquiry learning), Model Pembelajaran Berbasis Proyek (Project Based Learning), Model Pembelajaran Berbasis Masalah (Problem Based Learning), dan model pembelajaran lainnya yang memungkinkan peserta didik belajar secara aktif dan kreatif. Guru dapat memilih metode yang memungkinkan pencapaian tujuan pembelajaran pada kondisi darurat. Guru secara kreatif mengembangkan metode pembelajaran aktif yang disesuaikan dengan karakteristik materi/tema.

4. Media dan Sumber Belajar

Pada prinsipnya segala benda yang sesuai dapat dijadikan media pembelajaran.Guru diharapkan kreatif dan inovatif untuk memanfaatkan benda tersebut menjadi media agar dapat membantu tercapainya tujuan pembelajaran. Beberapa contoh media pembelajaran sederhana antara lain: Gambar, Peta dan Globe, Grafik, Papan Tulis, Papan Flanel, Display, Poster, Bagan (Chart), dan sebagainya. Pemilihan media disesuaikan dengan materi/tema yang diajarkan dan tagihan sesuai indikator dan tetap mempertimbangkan kondisi kedaruratan.

5. Perencanaan Pembelajaran di Masa Darurat

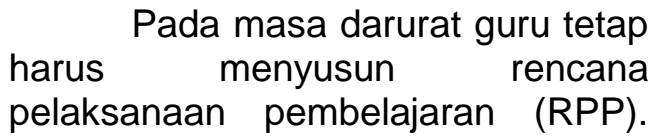

Dalam menyusun RPP, guru harus merujuk pada SKL, KI-KD dan dan Indikator Pencapaian yang diturunkan dari KD. Guru dapat membuat pemetaan KD dan memilih materi esensi yang akan di ajarkan kepada peserta didik pada masa darurat. Dalam setiap menyusun RPP, terdapat 3 (tiga) ranah yang perlu dicapai dan perlu diperhatikan pada setiap akhir pembelajaran, yaitu dimensi sikap, aspek pengetahuan dan aspek keterampilan.

Dimensi sikap mencakup nilianilai spiritual sebagai wujud iman dan takwa kepada Allah Swt, mengamalkan akhlak yang terpuji dan menjadi teladan bagi keluarga masyarakat dan bangsa, yaitu sikap peserta didik yang jujur, disipilin, tanggungjawab, peduli, santun, mandiri, dan percaya diri dan berkemauan kuat untuk mengimplementasikan hasil pembelajarannya di tengah kehidupan dirinya dan masyarakatnya dalam rangka mewujudkan kehidupan beragama, bermasyarakat, berbangsa, dan bernegara yang lebih baik.

Dimensi pengetahuan yaitu memiliki dan mengembangkan pengetahuan secara konseptual, faktual, prosedural dan metakognitif secara teknis dan spesifik dari tingkat sederhana, kongkrit sampai abstrak, komplek berkenaaan dengan pengembangan ilmu pengetahuan, teknologi, seni, budaya masyarakat sekitar, lingkungan alam, bangsa, negara dan kawasan regional, nasional maupun internasional.

Dimensi keterampilan yaitu memiliki keterampilan berpikir tingkat tinggi dan bertindak: kreatif, produktif, kritis, mandiri, kolaboratif, dan komunikatif serta mampu bersaing di era global dengan kemampuan sikap, pengetahuan dan keterampilan yang dimiliki.

Perencanaan pembelajaran dapat menggunakan edaran Menteri 
Pendidikan Nomor 14 Tahun 2019 tentang penyederhanaan RPP di mana unsur yang ditulis cukup tujuan pembelajaran, langkahlangkah pembelajaran, dan penilaian.

6. Kegiatan Pembelajaran di Masa Darurat

Kegiatan di masa darurat harus memperhatikan berbagai aspek dan regulasi. Salah satu regulasi penting yang harus dijadikan rujukan adalah SKB 4 Menteri (Menteri Pendidikan, Menteri Agama, Menteri Kesehatan, dan Menteri dalam Negeri). Kegiatan pada masa darurat terbagi atas zona masing-masing daerah. Hanya zona hijau yang dapat melaksanakan pembelajaran tatap muka dengan dua fase yakni fase transisi dan fase new normal. Selain itu harus memperhatikan protokol kesehatan dan memperoleh rekomendasi dari dinas kesehatan. Sedangkan zona merah, kuning, dan oranye tidak dapat melaksanakan pembelajaran tatp muka.

Atas dasar regulasi tersebut diperlukan pendekatan yang situasional sesuai resources yang dimiliki setiap lembaga. Kegiatan pembelajaran dapat berupa daring (dalam jaringan) maupun luring (luar jaringan). Stakeholders sekolah/madrasah diharapkan kreatif dalam membuat media untuk kegiatan pembelajaran yang sekiranya murah namun efektif dan efisien.

7. Penilaian Hasil Belajar

Penilaian hasil belajar mengacu pada regulasi/ juknis penilaian hasil belajar dengan penyesuaian masa darurat. Bentuk penyesuaian sangat kondisional tergantung infrastruktur pendukung masing-masing sekolah/madrasah.

\section{SIMPULAN}

Berdasarkan pembahasan di atas dapat ditarik kesimpulan bahwa kurikulum darurat memiliki fleksibilitas yang tinggi. Satuan pendidikan diberi ruang yang luas untuk mendesain struktur kurikulum, kegiatan pembelajaran, dan media pembelajaran dengan tetap berorientasi pada pengembangan pengetahuan, pengauatan karakter, dan peningkatan keterampilan dengan berangkat pada regulasi dan protokol kesehatan.

\section{DAFTAR PUSTAKA}

Aji, Rizqon Halal Syah. Dampak Covid-19 pada Pendidikan di Indonesia: Sekolah, Keterampilan, dan Proses Pembelajaran. SALAM; Jurnal Sosial \& Budaya Syar-i FSH UIN Syarif Hidayatullah Jakarta Vol. 7 No. 5 (2020)

Edaran Menteri Pendidikan Nomor 14 Tahun 2019 tentang Penyederhanaan RPP

Keputusan Bersama
Pendidikan Dan Kebudayaan,
Menteri Agama, Menteri
Kesehatan, Dan Menteri Dalam
Negeri Republik Indonesia
Tentang
Penyelenggaraan Pembelajaran
Pada Tahun Ajaran 2020/2021
Dan Tahun Akademik 2020/2021
Di Masa Pandemi Corona Wrus
Disease-19

Keputusan Bersama Menteri Pendidikan Dan Kebudayaan, Menteri Agama, Menteri Kesehatan, Dan Menteri Dalam Negublik Indonesia Tentang Penyelenggaraan Pembelajaran Pada Tahun Ajaran 2020/2021 Dan Tahun Akademik 2020/2021 Disease-19 
Keputusan Direktur Jenderal

Pendidikan Islam Nomor 3751

Tahun 2018 Tentang Petunjuk

Teknis Penilaian Hasil Belajar

Pada Madrasah Aliyah.

Keputusan Direktur Jendral

Pendidikan Islam Nomor 2781

Tahun 2020 tentang Panduan

Kurikulum Darurat pada

Madrasah

UU No 20 Tahun 2003 tentang Sistem

Pendidikan Nasional 